\title{
Barns rett til lek og utdanning i barnehagen
}

\section{Hanne Fehn Dahle}

Høgskolen $i$ Innlandet

\section{SAMMENDRAG}

Det har skjedd store endringer i barnehagesektoren i Norge de siste årene. Barnehagen har blitt et sentralt utdanningspolitisk satsingsområde, de største private barnehagekjedenes eierandel har økt vesentlig og barnehagepedagogikken er blitt et attraktivt marked for produsenter av standardiserte programmer og manualer.

I denne artikkelen diskuteres ulike ideer om utdanning og vilkårene for barns rettigheter basert på tekstanalyse av 100 årsplaner for barnehager. Det er gjort en kvantitativ innholdsanalyse for å kartlegge forekomsten av ord og begreper innenfor kategoriene deltakelse, utdanning, omsorg og lek, hvile og fritid.Videre er et utvalg av 25 årsplaner analysert kvalitativt. Et av hovedfunnene er at større barnehager drevet som aksjeselskap, barnehager som kjøper programmer utenfra og barnehager tilknyttet Agderprosjektet, har en tendens til å vektlegge utdanning og læring i større grad enn omsorg, hvile og lek. Artikkelen avsluttes med en drøfting av mulige drivkrefter som kan ha innvirkning på barnehagepedagogikken.

Nøkkelord: Lek; utdanning; marked; konkurranse

\section{ABSTRACT \\ Children's right to play and education in day care centers}

The Norwegian Early Childhood Education and Care (ECEC) institutions have undergone significant changes over the last ten years. The idea of the ECEC institution as a learning area has been brought more into the foreground. With the increase in the number of for-profit actors in the field, Early Childhood Education and Care has become an attractive market for producers of educational services.

Based on 100 local curricula, the aim of this article is to discuss the conditions for children's rights in day care centers. The research techniques are quantitative content analysis, and qualitative idea analysis of 25 curricula. One main finding is that profit-based childcare may tend to favor structured learning activities at the expense of time and space for social play. The article concludes by drawing attention to whether market dynamics involve moving the focus from children to the results.

\section{Keywords: Play; education; market; competition}

Mottatt: Juni, 2019; Antatt: Februar, 2020; Publisert: Juni, 2020

\footnotetext{
^Korrespondanse: Hanne Fehn Dahle, epost: hanne.fehn.dahle@inn.no

(C) 2020 Hanne Fehn Dahle. This is an Open Access article distributed under the terms of the Creative Commons Attribution 4.0 International License (https://creativecommons.org/licenses/by-nc/4.0/), allowing third parties to copy and redistribute the material in any medium or format and to remix, transform, and build upon the material for any purpose, even commercially, provided the original work is properly cited and states its license.

Citation: Hanne Fehn Dahle. "Barns rett til lek og utdanning i barnehagen» Nordisk tidsskrift for pedagogikk og kritikk, Vol. 6, 2020, pp. 100-114. http://dx.doi.org/10.23865/ntpk.v6.2055
} 


\section{Innledning}

Små barn har et særskilt behov for omsorg. De må gis tid til lek, utforsking og læring, samt sikres muligheten til å uttrykke meninger og følelser (De forente nasjoner, 2005, s. 3). Alle som arbeider med barn i Norge, er forpliktet til å forholde seg til artiklene i barnekonvensjonen (FNs konvensjon om barns rettigheter, 1989) og barnekomiteens ${ }^{1}$ kommentarer til disse (Øksnes \& Sundsdal, 2018, s. 26). I barnekonvensjonen er det fire artikler som er spesielt relevante for barnehagen, og som skal sikre ivaretakelsen av små barns særskilte behov. Disse er retten til beskyttelse og sikkerhet, deltakelse, utdanning, omsorg, lek, hvile og fritid.

Det har de siste årene skjedd store endringer i barnehagesektoren i Norge. Utdanning har blitt et sentralt politisk satsingsområde, og barnehagen betraktes som en viktig arena for et livslangt læringsløp (Finansdepartementet, 2018-2019). Dette har medført økt vektlegging av barndommen som forberedelse til videre utdanning og voksenliv, og av barns læring og måloppnåelse i barnehagen (Nygård, 2017, s. 3). Flere forskere har pekt på at denne dreiningen kan forstås som et brudd med den nordiske barnehagetradisjonen, en tradisjon der det gis plass til lek, utfoldelse, spontanitet og lite voksenstyring (se for eksempel Bae, 2018; Berge, 2015; Greve, 2015; Greve, Jansen \& Solheim, 2014; Nygård, 2017; Seland, 2011).

Parallelt med at utdanning har blitt et satsingsområde har de største private barnehagekjedenes eierandel økt vesentlig (Kunnskapsdepartementet, 2018, s. 6), og barnehagepedagogikken er nå et attraktivt marked for produsenter av standardiserte programmer og manualer (Pettersvold \& Østrem, 2012, 2019). Dette kan ses i sammenheng med en global utdanningstrend der private selskaper ikke bare drifter institusjonene, men også påvirker innholdet og pedagogikken (Ball \& Youdell, 2007).

I Norge kan barnehagetilbudet gis både av offentlige og private barnehager. Den statlige styringen har, inntil nylig, vært slik at kommunen har vært pålagt å finansiere alle private barnehager som følger minstekravene, definert av barnehageloven (2018). Kommunen kan i liten grad regulere det pedagogiske innholdet i de private barnehagene (Børhaug, 2016, s. 107-110).

Flere har undersøkt metodikken i standardiserte programmer og manualer og barnehagelæreres møte med disse (Buus, 2019; Pettersvold \& Østrem, 2012, 2018; Aabro, 2016; Aabro, Larsen \& Pedersen, 2017). Det er tidligere gjort lite forskning på private aktørers betydning for det pedagogiske innholdet i barnehagen, til tross for at det er nærliggende å anta at utviklere av programmer og eiere av større barnehagekjeder påvirker hva barnehagene vektlegger.

I denne artikkelen vil jeg undersøke følgende problemstilling:

\section{Hvilke ideer om utdanning forvalter barnehager med ulik eierstruktur?}

\footnotetext{
${ }^{1}$ Barnekomiteen består av eksperter på barns rettigheter. Komiteen utgir generelle kommentarer om tolkningen av enkelte artikler i barnekonvensjonen eller særlig viktige spørsmål.
} 


\section{H. F. Dahle}

For å finne svar på dette spørsmålet har jeg analysert 100 årsplaner fra forskjellige typer barnehager. I analysen av materialet har jeg tatt utgangspunkt i fire artikler i barnekonvensjonen og to tolkninger av begrepet utdanning (education). Jeg har gjort en kvantitativ innholdsanalyse for å kartlegge forekomsten av ord og begreper innenfor kategoriene deltakelse, utdanning, omsorg og lek, hvile og fritid. Disse kategoriene er valgt fordi jeg er opptatt av vilkårene for å realisere barns rettigheter, slik de er formulert i barnekonvensjonen. Videre har jeg gjort en kvalitativ idéanalyse av et utvalg av 25 barnehageårsplaner.

\section{To forståelser av utdanning}

Materialet diskuteres med utgangspunkt i to forståelser av utdanning, basert på to forskjellige tolkninger av etymologien av begrepet education. Disse representerer ulike tradisjoner med ulike ideer om hva utdanning er og bør være. Den ene tolkningen går ut på at begrepet educate har sin opprinnelse i educare, som betyr forme, trene, fø eller mate. Den andre tolkningen legger til grunn at begrepet educate kommer fra educere, som betyr lede, bringe ut eller springe ut. Begge tradisjonene hevder at de har den rette etymologiske definisjonen av educo, education (Schofield, 2011, s. 32, 65).

Educare beskriver en bevegelse utenfra og inn. I denne tradisjonen gis pedagogen en aktiv rolle og har stor innvirkning på resultatet. Barnet blir formet av pedagogen. Det finnes ikke noe medfødt som kan få utfolde og utvikle seg, og da heller ikke noe medfødt som setter grenser for hva man kan bli. Kunnskaper, kvalifikasjoner og ferdigheter formes av samfunnets og kulturens behov og idealer.

Educere innebærer en idé om at naturen er virksom i seg selv. Mennesker har et medfødt potensial og medfødte egenskaper som bestemmer hvordan barnet utvikler seg. I en slik tenkning har pedagogen en underordnet betydning. Barnet må få tid, plass og muligheter til å utvikle seg i fred. Inngripen fra voksne kan forstyrre og skade den naturlige utviklingen. Den kunnskapen barnet kommer frem til, er dermed ikke tilført utenfra, men noe som kommer innenfra. Selvutfoldelse og det å gjøre egne erfaringer står sentralt i educere-ideen (Kvernbekk, 2016, s. 121-123). Læringen skjer i spontane aktiviteter (Schofield, 2011, s. 65).

\section{Metode}

Undersøkelsen som ligger til grunn for denne artikkelen er en kvalitativ dokumentanalyse av 100 barnehagers årsplaner, ${ }^{2}$ der jeg har valgt å kombinere kvantitativ innholdsanalyse med kvalitativ idéanalyse. Tekstene ble først frekvenskartlagt ut fra følgende kategorier (artikler) i barnekonvensjonen: deltakelse (art. 12), utdanning

\footnotetext{
${ }^{2}$ Ifølge barnehageloven $\$ 2$ skal hver barnehage fastsette en årsplan for den pedagogiske virksomheten. Årsplanen er et arbeidsredskap for barnehagepersonalet, den skal dokumenterer barnehagens valg og begrunnelser, samt gi informasjon om barnehagens pedagogiske arbeid (Barnehageloven, 2018, $\$ 2$ ).
} 
(art. 28), omsorg, beskyttelse og sikkerhet (art. 3 nr. 2) og lek, hvile og fritid (art. 31). Videre ble et utvalg på 25 årsplaner analysert kvalitativt.

Den kvantitative innholdsanalysen har jeg valgt å betrakte som en grovsortering av materialet. Som Bratberg (2014, s. 93) skriver, er innholdsanalyse særlig interessant om den kombineres med andre tilnærminger som trenger ned i materialet. Den kvantitative innholdsanalysen kan støtte opp om den kvalitative analysens konklusjoner, og ifølge Bergström og Boréus (2012, s. 51) kan kvantitativ innholdsanalyse lett gli over i idéanalyse. Gitt at forskeren ønsker å gå bakenfor resultatene og drøfte hvilke idéer disse bygger på, kan det nettopp være en fordel å kombinere disse to analysemetodene.

\section{Kvantitativ innholdsanalyse - utvalg og gjennomføring}

Termen innholdsanalyse anvendes om analyser der tilnærmingen består i å kvantifisere, og på den måten systematisk beskrive tekstinnholdet (Bergström \& Boreús, 2012, s. 50). I denne delen av undersøkelsen har jeg tallfestet enheter $\mathrm{i}$ årsplanene, målt dem i frekvens og omfang, for deretter å sammenligne analyseenhetene innenfor hver gruppe av barnehager med de andre gruppene.

Analysen er styrt etter forhåndsdefinerte analytiske kategorier. Jeg ønsket å spore vektleggingen av barns rett til deltakelse, utdanning, omsorg og lek, hvile og fritid. Det betyr også at analysen er deduktiv, i analytisk forstand, fordi kodeskjemaet satte rammene for analysen.

Barnehagene ble i utgangspunktet delt inn i to grupper: kommunale og private barnehager. I starten av analysen så jeg imidlertid at det i flere av årsplanene ble vist til programmer eller spesielle manualer barnehagene arbeidet ut fra. Noen hadde også likelydende tekst i beskrivelsen av mål og arbeidsmåter. Dette gjaldt både kommunale barnehager som viste til programmer, og større barnehagekjeder som beskrev et felles konsept. Det gjorde meg oppmerksom på at variasjonen mellom barnehagene ikke nødvendigvis hadde sammenheng med om de var kommunale eller private. Som følge av dette valgte jeg derfor å dele de kommunale barnehagene i to grupper: kommunale barnehager i kommuner som kjøper programmer utviklet av eksterne aktører, og kommunale barnehager i kommuner som ikke gjør det. De private barnehagene delte jeg også i to grupper: enkeltstående private barnehager drevet av stiftelser (videre kalt stiftelsesbarnehager) og større barnehagekjeder organisert som aksjeselskap (videre kalt aksjebarnehager). Denne grupperingen gjør at noen barnehagekjeder ikke er med, som for eksempel Steinerbarnehagene og Kanvas. I hver av disse fire barnehagegruppene lastet jeg opp 20 årsplaner. I løpet av analyseprosessen ble en femte gruppe barnehager lagt til.

Innenfor privat barnehagedrift er det noen store selskaper som dominerer, som eier opp mot to hundre barnehager. Disse selskapene har oversiktlige hjemmesider, og det var enkelt å laste opp årsplaner fra barnehager med en viss geografisk spredning. Videre gjorde jeg søk på private, enkeltstående barnehager drevet som stiftelser. Disse er i all hovedsak foreldredrevne barnehager, men her finnes også 


\section{H. F. Dahle}

menighetsbarnehager og barnehager drevet av husmorlag eller andre private stiftelser. Utvalgskriteriet for de kommunale barnehagene som benytter programmer var om de programmene som ble brukt, var utviklet av kommunen selv eller av eksterne aktører. Dette var en omstendelig utvelgelse, da jeg måtte lese kommunale barnehageplaner og politiske dokumenter, samt gjøre søk på hjemmesidene til hvert enkelt program. ${ }^{3}$ I gruppen av kommunale barnehager i kommuner som ikke kjøper programmer, var det vanskelig å sikre prinsippene om geografisk spredning og variasjon i kommunestørrelse. Jeg fant ingen store kommuner som ikke kjøper programmer til bruk i sine barnehager.

Jeg startet med å utvikle et kodeskjema og en kodeinstruks. For å komme frem til hvilke ord som skulle brukes i kodeskjemaet brukte jeg barnekomiteens tolkninger av de aktuelle artiklene (GC/1, 2001; GC/7, 2005; GC/12, 2009; GC/14, 2013; GC/17, 2013).

Følgende kodeskjema ble brukt i analysen av årsplanene:

\begin{tabular}{llll}
\hline Deltakelse & Medvirkning & Lek, hvile og fritid & Lek (fri) \\
Art. 12 & Delta & Art. 31 & Hvile \\
& Demokrati & & Søvn/sove \\
& Uttrykke & & Ro/rolig \\
& Meninger & & Kultur \\
& Ytring(sfrihet) & & Spontan \\
& Påvirke & & Opplevelser \\
\hline Utdanning & Lære/læring & Omsorg, beskyttelse og & Omsorg \\
Art. 28 & Kunnskap & sikkerhet & Trygghet/trygg/trygge \\
& Utforsking & Art 3, nr. 2 & Trivsel \\
& Kompetanse & & Sikkerhet \\
& Skole & & Hygiene \\
& Lek (knyttet til læring) & & Mat/måltid \\
& Ferdigheter & & Stell/bleieskift \\
\hline
\end{tabular}

Først gjennomførte jeg en prøveanalyse av en mindre del av materialet. Jeg hadde som nevnt delt barnehagene inn i fire grupper. Under prøveanalysen oppdaget jeg at kategorien utdanning gjorde store utslag i noen av barnehagene på tvers av gruppene. Ved nærmere undersøkelse oppdaget jeg at det de hadde til felles var tilknytning til Agderprosjektet. ${ }^{4}$ Jeg bestemte meg derfor for å ha med barnehager tilknyttet dette prosjektet som en femte gruppe barnehager.

\footnotetext{
${ }^{3}$ Eksempler på programmer som ble brukt er: TRAS, DUÅ, Alle med, Steg for steg, MIO, Språkglede i barnehagen.

${ }^{4}$ Agderprosjektet er et forsknings- og utviklingsprosjekt tilknyttet UiS og UiA. Prosjektet tester ut en metode som kalles Lekbasert læring i 50 barnehager. Det legges opp til førskoleaktiviteter minst to timer fire dager i uken. Både kommunale og private barnehager er tilknyttet prosjektet (www. uis.no).
} 
Prøveanalysen hjalp meg til å videreutvikle kodeinstruksene, ${ }^{5}$ som inneholdt hvilke vurderinger jeg skulle gjøre om jeg ble i tvil om hvordan ord og setninger skulle tolkes. I kodeinstruksen stod det for eksempel at jeg skulle tolke hvert av ordene i den sammenhengen de står skrevet. Jeg måtte derfor lese hele setningen eller avsnittet. Ord og begreper skulle telles med om de knyttet seg til barn. Begrepet medvirkning kunne for eksempel forekomme både i forbindelse med barns medvirkning og foreldres medvirkning, og kompetanse kunne både knytte seg til barns kompetanse og personalets kompetanseutvikling. Dette medførte at jeg ikke bare kunne telle antall ganger et ord forekom i teksten, men måtte vurdere om det var snakk om voksne eller barn ut fra sammenhengen det stod skrevet i. Lek registrerte jeg enten som lek knyttet til læring eller lek forstått som barnekonvensjonens tolkning av begrepet lek, som er fri og spontan lek som ikke har et mål utover seg selv (jf. Øksnes \& Sundsdal, 2018, s. 29). Det betyr for eksempel at mattelek ble kategorisert som lek knyttet til læring, mens frilek ble kategorisert kun som lek.

Jeg gikk først gjennom en tekst fra den ene gruppen, så den andre, så den tredje og så videre. Slik gikk jeg frem og tilbake mellom gruppene. Til slutt talte jeg opp forekomsten av ord innenfor de fire kategoriene, fordelt på de fem forhåndsbestemte gruppene. Etter opptellingen så jeg at det i noen grupper var relativt høye tall innenfor alle kategoriene, mens det $\mathrm{i}$ andre grupper var mye lavere tall. Dette kom av at barnehagenes årsplaner hadde svært ulik lengde. Årsplanene til stiftelsesbarnehagene kunne for eksempel være på opptil 25 sider, mens årsplanene til barnehagene i en av kommunene som kjøper programmer utenfra kun var på tre sider. Dette gjorde det vanskelig å sammenligne tallene direkte. Jeg valgte derfor å regne om til prosent, der det totale antallet frekvenstalte ord innen hver gruppe utgjør 100 prosent.

\section{Kvalitativ idéanalyse - utvalg og gjennomføring}

For idéanalysen er tolkningen overordnet, og tilstedeværelse av visse ideer i materialet er viktigere enn frekvens (Beckman, 2005, s. 44, 50). Ideene behøver ikke å være eksplisitte for å kunne analyseres. Det ligger i forskerens oppgave å tolke et utsagn som uttrykk for bestemte ideer (Bratberg, 2014, s. 79). I en av årsplantekstene står det for eksempel at «barns egne interesser og spørsmål bør danne grunnlaget for læringsprosesser og temaer i barnehagen». Det beskriver et ønske om å ta utgangspunkt i spørsmål eller interesser uttrykt av barna. Samtidig kan jeg lese dette som en forestilling om at utdanning kommer innenifra.

Den største ulikheten mellom gruppene av barnehager fant jeg innen kategorien utdanning. Derfor ville jeg undersøke hvordan barnehagene argumenterte for utdanning, og om en analyse av argumentene kunne indikere ulike ideer om hva utdanning er og bør være.

\footnotetext{
${ }^{5}$ Dette var instruksjoner til meg selv, satt opp i forkant av analysen, som hjalp meg til å være konsekvent i mine tolkninger.
} 


\section{H. F. Dahle}

Av de 100 årsplanene valgte jeg ut fem fra hver gruppe av barnehager, til sammen 25 årsplaner. Disse gikk jeg først gjennom en gang, mens jeg streket under det jeg tolket som argumenter for utdanning i teksten. Deretter formulerte jeg en tese, $\mathrm{i}$ form av en spissformulering: Formålet med utdanning $i$ barnehagen er å optimere barnas fremtidige skoleprestasjoner. Deretter leste jeg planene en gang til, og skrev ned de proog kontraargumentene jeg fant i tekstene. Det første proargumentet fikk betegnelsen PRO1. Kontraargumentet som ble satt opp mot PRO1 fikk betegnelsen KONTRA1. Det hele ble sammenfattet i et skjema med seks proargumenter og seks kontraargumenter. Det første proargumentet jeg satte opp, så slik ut: «Det legges vekt på ferdigheter som barnet har bruk for ved skolestart» (PRO1). Mot dette proargumentet satte jeg opp følgende kontraargument: «Barns egne interesser og spørsmål bør danne grunnlaget for læringsprosesser og temaer i barnehagen» (KONTRA1). Jeg tok med alle argumenter som ut fra mine tolkninger kunne settes opp som pro- eller kontraargumenter til spissformuleringen. Vurderingene av hvilke argumenter som ble satt opp som pro- og kontrapar, var basert på mine tolkninger av om argumentene kunne sies å omhandle det samme temaet. Noen argumenter kunne ha nærmest identisk formulering. Setningen «Barnehagen skal ses på som første trinn i utdanningsløpet» leste jeg for eksempel i flere av årsplanene. Setningen ble da skrevet ned som et proargument. Nye setninger ble lagt til i skjemaet dersom de, ut fra mine tolkninger, representerte et nytt argument.

\section{Resultater av analysene}

I denne delen presenterer jeg resultatene fra den kvantitative innholdsanalysen, og deretter den kvalitative idéanalysen.

\section{Den kvantitative innholdsanalysen}

Frekvenskartleggingen av ord, fordelt på grupper av barnehager og kategoriene deltakelse, utdanning, lek, hvile og fritid og omsorg, beskyttelse og sikkerhet, er presentert i tabellen under. Det totale antallet frekvenskartlagte ord er regnet om til prosent. Hver gruppe av barnehager utgjør 100 prosent.

Alle gruppene vektlegger retten til utdanning i sine årsplaner. Kommunale barnehager i kommuner som ikke kjøper programmer skriver mest om deltakelse, mens barnehager tilknyttet Agderprosjektet omtaler dette minst. Benevning av utdanning får høyest skår i årsplanene til barnehager tilknyttet Agderprosjektet, og lavest i de enkeltstående stiftelsesbarnehagene og hos kommunale barnehager i kommuner som ikke kjøper programmer. Lek, hvile og fritid skrives i større grad frem i årsplanene til stiftelsesbarnehagene og barnehager i kommuner som ikke kjøper programmer, og lavest i barnehagene tilknyttet Agderprosjektet. Når det gjelder omsorg, beskyttelse og sikkerhet, er det ingen store forskjeller mellom de fem gruppene, selv om stiftelsesbarnehagene omtaler dette området mest. 


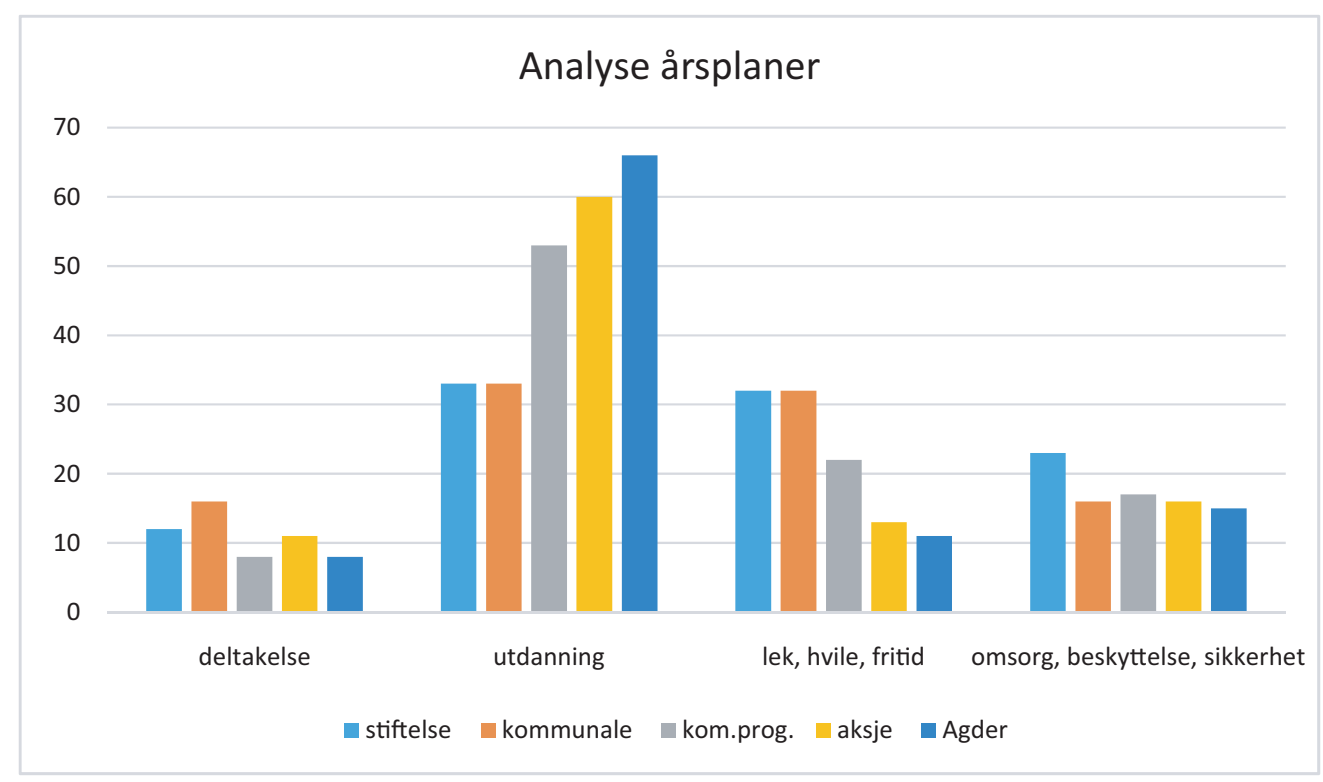

Figur 1. Stiftelse: private, enkeltstående barnehager drevet av stiftelser. Kommunale: kommunale barnehager i kommuner som ikke kjøper programmer utenifra. Kom.prog.: kommunale barnehager i kommuner som kjøper programmer. Aksje: Større kjeder av private barnehager organisert som aksjeselskap. Agder: barnehager tilknyttet Agderprosjektet.

Den største variasjonen finner jeg i vektleggingen av utdanning. Aksjebarnehager, barnehager i kommuner som kjøper programmer fra eksterne aktører og barnehager tilknyttet Agderprosjektet skriver mest om hva barna skal lære i barnehagen, mens stiftelsesbarnehager og kommunale barnehager i kommuner som ikke kjøper programmer, legger minst vekt på dette.

\section{Idéanalyse av årsplanene}

Den kvantitative grovsorteringen viser at utdanning er den rettigheten for barn som samlet sett vektlegges mest $i$ årsplanene. Det ser også ut til at jo mer utdanning blir vektlagt, dess mindre blir lek, hvile og fritid beskrevet. Alle årsplanene fremhever betydningen av utdanning, men det varierer hva de vektlegger som viktigst og hvordan de argumenterer for utdanningens plass i barnehagen. Den største uenigheten, og den kanskje mest betydningsfulle ideologiske forskjellen, finner jeg i deres eksplisitte stillingtagen til hvorvidt barnehagen skal tenkes som en integrert del av en overordnet utdanningsstrategi der formålet er å optimere fremtidige elevers skoleprestasjoner eller ikke. I analysen av argumentene i årsplanene har jeg derfor valgt å sette opp tesen som gikk ut på at formålet med utdanning i barnehagen er å optimere barnas fremtidige skoleprestasjoner. Jeg presenterer seks proargumenter og seks kontraargumenter til denne systematisert i skjemaet under: 


\section{H. F. Dahle}

\begin{tabular}{ll}
\hline Formålet med utdanning i barnehagen er å optimere elevers skoleprestasjoner \\
\hline Proargumenter & Kontraargumenter \\
\hline $\begin{array}{l}\text { PRO1: Det legges vekt på ferdigheter som barnet har } \\
\text { bruk for ved skolestart (aksjebarnehage). }\end{array}$ & $\begin{array}{l}\text { KONTRA1: Barns egne interesser og spørsmål bør } \\
\text { danne grunnlaget for læringsprosesser og temaer i } \\
\text { barnehagen (stiftelsesbarnehage). }\end{array}$ \\
PRO2: Barnehagen skal ses på som første trinn i & $\begin{array}{l}\text { KONTRA2: Vi vil at barn skal få være barn } \\
\text { (stiftelsesbarnehage). } \\
\text { PROanningsløpet (aksjebarnehage). }\end{array}$ \\
nivå enn det levekårsindeksen og foreldrenes & KONTRA3: Barnet skal få kjenne i hele seg at det er \\
\end{tabular}

utdanningsnivå skulle tilsi (kommunal, som kjøper program).

PRO4: Målet er å bidra til at barnehagebarn skal prestere bedre i matematikk og naturfag i skolen (aksjebarnehage).

PRO5: Målsettingen er å bidra til at barn i større grad har samme læringsgrunnlag ved skolestart, og dermed like muligheter til å lykkes i utdanningsløpet og arbeidslivet (Agderprosjektet).

PRO6: Barnehagen skal bidra til økt oppmerksomhet på realfagenes betydning, både for at flere elever skal fullføre og bestå videregående opplæring, men også for å øke interessen for realfag (kommunal, som

KONTRA4: Den uformelle læringen er størst. Det er den læringen som tilegnes i hverdagen gjennom samhandling med andre (stiftelsesbarnehage).

KONTRA5: Det er store individuelle forskjeller på kva tid barn er klare for ny læring (kommunal, som ikke kjøper program).

KONTRA6: Personalet skal tilrettelegge for aktiviteter ut fra barnas ståsted, interesser og behov (kommunal, som kjøper program).

kjøper program).

Det første proargumentet (PRO1) er at barnehagen legger «vekt på ferdigheter som barnet har bruk for ved skolestart». Skolen legger her premissene for hva som skal vektlegges i barnehagen. Det pedagogiske innholdet blir bestemt utenfor barnehagen, uavhengig av de barna som går der. I kontraargumentet (KONTRA1) understreker barnehagen at barnas utvikling er avgjørende for det pedagogiske innholdet: «Barns egne interesser og spørsmål bør danne grunnlaget for læringsprosesser og temaer i barnehagen». Argumentet gir uttrykk for at det ikke bare bør være de voksne i barnehagen som bestemmer hva barna skal lære, men at dette er noe som skal komme fra barna selv.

Det andre proargumentet (PRO2) sier at «barnehagen skal ses på som første trinn i utdanningsløpet». I dette leser jeg at barnehagen knyttes sammen med skolen, muligens også til videre studier. Dette kan kobles til en tenkning om at utdanning er noe mennesket driver med hele livet, og at startskuddet går i barnehagen. Kontraargumentet (KONTRA2) "Barn skal få være barn» kan tolkes som et argument for å skjerme små barn mot krav, ansvar og forventninger som møter dem senere i livet. Det kan også tolkes som et syn på barnet som det naturlige, lekende og frie, som i størst mulig grad må få være i fred fra voksen intervensjon.

Det tredje proargumentet (PRO3) går ut på at «målet er å løfte elevmassen til et høyere nivå enn det levekårsindeksen og foreldrenes utdanningsnivå skulle tilsi». 
Barnehagebarna blir sett på som fremtidige elever, og barnehagens pedagogiske arbeid kan være med på å bryte sosial arv og høyne skoleresultatene i kommunen. Pedagogikken tenkes som et input-output-system, der input er kunnskapen barna får i barnehagen og output er målene satt av kommunen. I kontraargumentet (KONTRA3) «Barnet skal få kjenne i hele seg at det er verdifullt og vellykket» ligger derimot målet i barnet selv. Det er ikke satt opp normer eller mål utenfor barnet. Følelsen av å være verdifull kommer innenfra, noe som understrekes i adverbialet «i hele seg».

Målet i proargument fire (PRO4) er «å bidra til at barnehagebarn skal prestere bedre i matematikk og naturfag i skolen». Dette ligner på proargument tre. Begge har bedre skoleprestasjoner som mål. Her vises det imidlertid til barnehagebarna, og ikke elevmassen, og matematikk og naturfag er trukket frem som de viktigste fagene. Argumentet går ut på at det er viktig å prestere godt i disse to spesifikke fagene $\mathrm{i}$ skolen, og at barnehagen kan bidra til økte prestasjoner her. Den kausale verdien i bidra impliserer at endringer ett sted (i barnehagen) fører til endringer et annet sted (i skolen). Kontraargumentet (KONTRA4) vektlegger også læring, men på en annen måte: «Den uformelle læringen er størst. Det er den læringen som tilegnes i hverdagen gjennom samhandling med andre». Hvis barna leker sammen i barnehagen vil de lære seg det viktigste for barn på den alderen.

Proargument fem (PRO5) uttrykker målsettingen «å bidra til at barn i større grad har samme læringsgrunnlag ved skolestart, og dermed like muligheter til å lykkes i utdanningsløpet og arbeidslivet». De som har skrevet denne årsplanen mener at det er mulig for alle barn å lære det samme, og til samme tid. Innholdet i hva som skal læres er bestemt av hvilke krav som stilles i skolen, og senere i arbeidslivet. Utbytte, eller resultater, av barnehageoppholdet står i fokus. Kontraargumentet (KONTRA5) sier at barns utvikling skjer i ulikt tempo: «Det er store individuelle forskjeller på kva tid barn er klare for ny læring».

Proargument seks (PRO6) ligner på proargument fire (PRO4) ved at det bruker den kausale verdien bidra, og ved at realfag blir sett på som spesielt viktig. Forfatterne av årsplanen sier at «økt oppmerksomhet på realfagenes betydning» vil føre til at flere elever fullfører og består videregående opplæring. Intervensjon i barnehagen kan altså predikere et gitt utfall mange år senere. Kontraargument seks (KONTRA6) sier at "personalet skal tilrettelegge for aktiviteter ut fra barnas ståsted, interesser og behov». Dette ligner på kontraargument en (KONTRA1), ved at det understrekes at det pedagogiske innholdet $\mathrm{i}$ barnehagen må ta utgangspunkt i det som kommer fra barnas selv. Det spesielle med proargument seks og kontraargument seks er at argumentene er hentet fra samme barnehageårsplan, og de vil derfor kunne stå i konflikt med hverandre når personalet i denne barnehagen skal tolke årsplanen.

Oppsummert går proargumentene, slik jeg tolker dem, ut på at barnehagen er det første trinnet i utdanningsløpet, og at det er mulig for alle barn å lære det samme, til samme tid. Målene er satt av samfunnet, utenfor barnehagen, og skolens behov avgiør hva som skal vektlegges. Gjør man endringer i barnehagen, fører det til endringer i skolen. Barnehagen anses her å fungere som et input-output-system. 


\section{H. F. Dahle}

Kontraargumentene kan, slik jeg tolker dem, oppsummeres med at de vektlegger et syn på barn som naturlige, lekende og frie, og at de i størst mulig grad må få være $i$ fred fra voksen intervensjon. De voksne i barnehagen bør ikke bestemme hva barna skal lære, det skal komme fra barna selv, innenfra, basert på deres interesser, i lek og samhandling med andre barn.

\section{Ideer om utdanning som educare eller educere}

I diskusjonen om barnehagen som fundament for optimalisering av prestasjoner i skolen ser jeg det som mest nærliggende å identifisere ulike ideer om hva utdanning er. Kulturen eller samfunnets interesser på den ene siden (educare), og barnets interesser på den andre (educere). I praktisk pedagogisk arbeid trenger ikke disse å bli sett på som motsetninger (Schofield, 2011, s. 40). Men en todeling kan rydde og gi oversikt over ulik pedagogisk tenkning og tradisjon, og fungere som et analyseredskap når jeg videre vil forsøke å identifisere hvilke ideer om utdanning argumentasjonen i årsplanene bygger på.

Tanken om at det er mulig for alle barn å lære det samme, og til samme tid, slik at alle får «like muligheter til å lykkes i utdanningsløpet og arbeidslivet» (PRO5), kan leses inn i educare-tradisjonens viktige prinsipp om at det ikke er noe som er medfødt, og som kan sette grenser for hva man kan bli.

Synet på barn som naturlig lekende og frie kommer til uttrykk i utsagn som «barn skal få være barn» (KONTRA2) og «barnet skal få kjenne i hele seg» (KONTRA3). Dette viser til tanker om det naturlige barnet som er virksomt i seg selv, utdanning som educere, hvor det å være barn har en egenverdi som skal vernes.

At det skal «legges vekt på ferdigheter som barnet har bruk for ved skolestart» (PRO1) står i kontrast til ideen om at det ikke bør være de voksne i barnehagen som skal bestemme hva barna skal lære (KONTRA1). Den første ideen (PRO1) kan knyttes til den styrende pedagogrollen innen educare-tradisjonen, mens i den andre (KONTRA1) har pedagogen en mer underordnet betydning, som i educere-tradisjonen.

Utsagn som «bruk for ved skolestart» (PRO1), «matematikk og naturfag i skolen» (PRO4), «løfte elevmassen til et høyere nivå (PRO3) og "øke interessen for realfag» (PRO6) sier noe om kulturens og samfunnets interesser. Det er de kunnskaper, kvalifikasjoner og ferdigheter samfunnet til enhver til verdsetter og har behov for. Dette er formuleringer som skriver seg inn i educare-ideen om at innhold og mål i utdanningen skal bestemmes av samfunnet.

Ut fra idéanalysen av argumentasjonen i barnehagenes årsplaner kan det se ut som om større kjeder av aksjebarnehager, barnehager i kommuner som kjøper programmer utenfra og barnehager tilknyttet Agderprosjektet legger seg tettere opp til educare-tradisjonen enn stiftelsesbarnehager og barnehager i kommuner som ikke kjøper programmer. De to sistnevnte gruppene ser ut til i større grad å være en del av educere-tradisjonen. Dette er også sammenfallende med den kvantitative 
innholdsanalysen, som viste at stiftelsesbarnehagene og barnehager i kommuner som ikke kjøper programmer utenfra vektlegger lek, hvile og fritid. Aksjebarnehagene, barnehager i kommuner som kjøper programmer utenfra og barnehager tilknyttet Agderprosjektet skriver mer om hva barna skal lære i barnehagen.

Større kjeder av aksjebarnehager, barnehager i kommuner som kjøper programmer utviklet av eksterne aktører og barnehager tilknyttet Agderprosjektet argumenterer for å legge "vekt på ferdigheter som barnet har bruk for ved skolestart» (PRO1) eller «løfte elevmassen til et høyere nivå»(PRO3), og prioriterer utdanning som educare fremfor lek, hvile og fritid i sine årsplaner. Dette kan tolkes som at de ønsker å legge det pedagogiske innholdet i barnehagen tettere opp til skolen. Det vil i så fall representere et brudd med barnehagens educere-tradisjon, som definerer barnehagen som noe annet enn skole, der det skal gis plass til lek, utfoldelse, spontanitet og mindre voksenstyring.

Et slikt brudd kan ses som en oppfølging av politiske signaler fra myndighetene om økt vektlegging av barnehagen som forberedelse til videre utdanning. Barnehagene skal nå inngå som første trinn i utdanningsløpet, og være en forberedelsesfase før barna begynner på skolen (Bae, 2018; Greve, Jansen \& Solheim, 2014; Helsvig, 2017; Nygård, 2017; Thuen, 2017).

\section{Mulige drivkrefter i prosessen mot større vektlegging av utdanning}

Det er noen interessante likhetstrekk mellom aksjebarnehager, barnehager i kommuner som kjøper programmer fra eksterne aktører og Agderprosjektet. De vektlegger alle utdanning fremfor lek, hvile og fritid i sine årsplaner, og argumenterer for at skolen skal legge premissene for barnehagens innhold. Jeg vil i den videre drøftingen forsøke å finne premissene for resultatene.

Et spørsmål blir: Hva er det private aksjebarnehager har til felles med standardiserte programmer og verktøy? Kan jeg finne likheter mellom barnehagene i geografisk plassering, kommunestørrelse, antall barn per voksen, eierforhold, organisering eller barnehagens størrelse? Her fant jeg ingen likheter. Det er flere barn per voksen i private kjedebarnehager enn i andre barnehager (Lunder, Håkonsen \& Eira, 2018), men dette gjelder ikke kommunene som kjøper programmer utviklet av eksterne aktører. Barnehagene ligger spredt over hele landet, både i store og små kommuner. Utvalget av årsplaner var hentet fra en variasjon i barnehagestørrelse og organisering, og private aksjebarnehager og barnehager i kommuner som kjøper programmer har ulikt eierforhold.

Resultatene fra en masteroppgave skrevet av studenter ved Norges Handelshøyskole (Næsguthe \& Ravndal, 2018) peker i retning av at ikke-profittsøkende barnehager drives av indre motivasjon, og at profittsøkende barnehageeiere drives av ytre motivasjon. For å kunne tjene penger på barnehagedrift må private barnehageeiere selge tilstrekkelig med barnehageplasser til foreldrene. Tilsvarende må programutviklere selge programmene sine til kommunene for å kunne gå med økonomisk 


\section{H. F. Dahle}

overskudd. Det er nærliggende å anta at det programutviklere og eiere av private aksjebarnehager har til felles, er en ytre profittmotivasjon.

Dette gir imidlertid ikke svar på hvorfor aksjebarnehager og kommuner som kjøper programmer utenfra vektlegger utdanning og optimering av elevers skoleprestasjoner. Svaret på dette kan ligge i markedsorienteringen. Markedsorientering vil si at organisasjoner retter seg mot å imøtekomme kunders behov og ønsker (Andreassen \& Lunde, 2001, s. 62). Det innebærer at bedrifter tilpasser produktene til det de tror markedet ønsker ut fra de signalene markedet har gitt. Markedet forteller dermed foretakene at det kan «være lønnsomt å investere noe mer på et gitt område, eller redusere innsatsen på et annet område» (Andreassen \& Lunde, 2001, s. 67). Agderprosjektet er imidlertid et forskningsprosjekt, som ikke (foreløpig) retter seg mot barnehagene for å selge et produkt.

Konkurranse er en logisk konsekvens av en markedsstrukur (Rosa, 2010, s. 27). Den oppstår når flere produsenter ønsker å selge det samme produktet. Om det er flere produkter enn kjøpere, vil de som har det beste eller rimeligste produktet vinne, og få økt profitt (Andreassen \& Lunde, 2001, s. 165). Foreldre kan fritt velge barnehage for barna sine, så fremt det er ledige plasser. I flere områder av landet er det flere barnehageplasser enn det er barn (Børhaug \& Moen, 2014, s. 127). Barnehagene blir dermed satt i en situasjon der de må overbevise foreldrene om at deres barnehage kan tilby noe som er kvalitativt bedre enn det andre barnehager hevder å ha.

Det ser ut til at det som da blir tilbudt er det som vurderes å kunne gi barna bedre muligheter til å prestere videre i utdanningsløpet og senere arbeidslivet, og dermed gir dem et fortrinn i konkurransen med andre barn i skolen. Dette henger sammen med at konkurranse som drivkraft strekker seg langt ut over den økonomiske sfæren. Barnehager tilknyttet Agderprosjektet skriver i sine årsplaner at de «kan bidra til at barn i større grad har samme læringsgrunnlag ved skolestart, og dermed like muligheter til å lykkes i utdanningsløpet og arbeidslivet». Utsagnet impliserer at skolen representerer konkurransesituasjoner der det gjelder at «alle har det samme læringsgrunnlaget» og «like muligheter» ved start. Det forutsettes at skolen er en konkurransearena som kårer vinnere og tapere, og barnehagen skal gi barna en mulighet til å vinne, å «lykkes». Ikke her og nå i barnehagen, men en gang i fremtiden. Dermed blir barnehagen et sted barna kommer for å få kompetanser og ferdigheter de senere kan veksle inn i den rådende valutaen i et marked.

\section{Avsluttende refleksjoner}

I begynnelsen av artikkelen stilte jeg spørsmålet: Hvilke ideer om utdanning forvalter barnehager med ulik eierstruktur? Stiftelsesbarnehager og barnehager som ikke kjøper program utenfra ser ut til å være de som i størst grad vektlegger retten til lek, hvile og fritid, og dermed knytter seg til educere-tradisjonen. I årsplanene til større barnehagekjeder organisert som aksjeselskap, barnehager i kommuner som kjøper programmer utviklet av eksterne aktører og barnehager tilknyttet Agderprosjektet 
argumenteres det for at formålet med utdanning i barnehagen er å optimere elevers skoleprestasjoner. I dette ligger det på et vis et positivt syn på at det er mulig å gi alle barn et godt utgangspunkt for å gjøre det bra på skolen og senere i voksenlivet. Jeg mener likevel at det kan være betimelig å se kritisk på om dette innebærer at fokuset flyttes fra barna til resultater som fyller samfunnets behov for gode elever og arbeidstakere.

Jeg ser en fare for at de to ulike utdanningstradisjonene skiller lag og utkrystalliserer seg i to ulike barnehagetilbud: Et leke- og fritidstilbud i enkeltstående stiftelsesbarnehager og et skoleforberedende tilbud i større private barnehagekjeder drevet som aksjeselskap. Det foreldre kan komme til å stå overfor når de skal velge barnehagetilbud for sitt barn, kan bli om de skal la barnet være barn i fri lek og lære ut fra sine egne interesser og utvikling, eller om de skal la det begynne på skolen når det er et år gammelt for å kunne hevde seg i utdanningssystemet og arbeidslivet senere.

\section{Forfatteromtale}

Hanne Fehn Dahle er doktorgradskandidat ved doktorgradsprogrammet Barn og unges deltakelse og kompetanseutvikling (BUK) ved Høgskolen i Innlandet.

\section{Referanser}

Andreassen, T. W. \& Lunde, T. K. (2001). Offentlige tjenester - prinsipper for økt brukerorientering. Oslo: Universitetsforlaget.

Bae, B. (2018). Politikk, lek og lering. Barnehageliv fra mange kanter. Bergen: Fagbokforlaget.

Ball, S. J. \&Youdell, D. (2007). Hidden Privatisation in Public Education (Rapport for Education International). Hentet fra https://pages.ei-ie.org/quadrennialreport/2007/upload/content_trsl_images/630/Hidden_privatisation-EN. pdf

Barnehageloven. (2018). Lov om barnehager (LOV-2018-06-22-83). Hentet fra https://lovdata.no/lov/200506-17-64

Beckman, L. (2005). Grundbok i idéanalyse. Det kritiska studiet av politiska texter och idéer. Stockholm: Santérus Förlag.

Berge, A. (2015). Barnehagen $i$ en brytningstid: tradisjoner $i$ spill og praksiser under press $i$ den store barnehagen (Doktoravhandling, Universitetet i Stavanger). Hentet fra http://hdl.handle.net/11250/2367503

Bergström, G. \& Boréus, K. (2012). Textens mening och makt. Metodbok $i$ samhällsvetenskaplig text- och diskursanalys. Lund: Studentlitteratur.

Bratberg, Ø. (2014). Tekstanalyse for samfunnsvitere. Oslo: Cappelen Damm Akademisk.

Buus, A. M. (2019). Viden der virker. En etnografisk undersøgelse mellem småbørnspcedagogik og evidensbaseret metode (Doktoravhandling, Aarhus Universitet). Hentet fra https://www.ucviden.dk/portal/files/70591654/ Afhandling_Anne_Mette_Buus.pdf

Børhaug, K. (2016). Ulike eigarar - ulike læringssyn. I K. H. Moen, K.-Å. Gotvassli \& P.T. Granrusten (Red.), Barnehagen som leringsarena. Mellom styring og ledelse (s. 107-144). Oslo: Universitetsforlaget.

Børhaug, K. \& Moen, K. H. (2014). Politisk-administrative rammer for barnehageledelse. Oslo: Universitetsforlaget.

Barnekonvensjonen. (1989). FNs konvensjon om barnets rettigheter (Barne- og familiedepartementet). Hentet fra https://www.regjeringen.no/globalassets/upload/kilde/bfd/bro/2004/0004/ddd/pdfv/178931-fns_barnekonvensjon.pdf

De forente nasjoner. (2001). Generell kommentar nr. 1. Artikkel 29: Utdanningens formål. Hentet fra https://www. regjeringen.no/globalassets/upload/bld/barnets-rettigheter/generell-kommentar-1---25-6-09.pdf 


\section{H. F. Dahle}

De forente nasjoner. (2005). Generell kommentar $n r$. 7. Gjennomføring av barnets rettigheter i tidlig barndom. Hentet fra https:/www.regjeringen.no/globalassets/upload/bld/barnets-rettigheter/generell-kommentar-7.pdf

De forente nasjoner. (2009). Generell kommentar nr. 12. Barnets rett til å bli hørt. Hentet fra https://www. regjeringen.no/globalassets/upload/bld/barnets-rettigheter/generell-kommentar-12.pdf

Deforente nasjoner. (2013). Generell kommentarnr. 14. Barnets rett til at hans ellerhennes beste skal vare et grunnleggende hensyn. Hentet fra https:/www.regjeringen.no/contentassets/1376fac2fe2a427389f9f94b52acdefc/crc_c_ gc_14_eng_nor.pdf

De forente nasjoner. (2013). Generell kommentar nr. 17. Barnets rett til hvile, fritid, lek, fritidsaktiviteter, kulturliv og kunstnerisk virksomhet (art. 31). Hentet fra https://www.regjeringen.no/contentassets/1376fac2 fe2a427389f9f94b52acdefc/crc-c-gc-17_en_nor.pdf

Finansdepartementet. (2019). Muligheter for alle - Fordeling og sosial bcerekraft. (Meld. St. 13 (2018-2019)). Hentet fra https:/www.regjeringen.no/no/dokumenter/meld.-st.-13-20182019/id2630508/

Greve, A. (2015). Barnehagelærerprofesjonens utfordringer i møte med politiske forventninger om læringsutbytte. I B. A. Hennum, M. Pettersvold \& S. Østrem (Red.), Profesjon og kritikk (s. 201-219). Bergen: Fagbokforlaget.

Greve, A., Jansen, T. T. \& Solheim, M. (2014). Kritisk og begeistret. Barnehagelcerernes fagpolitiske historie. Bergen: Fagbokforlaget.

Helsvig, K. (2017). Reform og rutine. Kunnskapsdepartementets historie (1945-2017). Oslo: Pax forlag.

Kunnskapsdepartementet. (2018). Markedssvikt, lønnsomhet og gevinstrealisering $i$ barnehagesektoren (Rapport utarbeidet av BDO). Hentet fra https://www.regjeringen.no/contentassets/239671d772c2422199d3 d5b5fb3b4569/bdo_rapport_endelig.pdf

Kvernbekk, T. (2016). Educere og educare. I O. A. Kvamme, T. Kvernbekk \& T. Strand (Red.), Pedagogiske fenomener (s. 120-127). Oslo: Cappelen Damm Akademisk.

Lunder, T. E., Håkonsen, L. \& Eika, B. (2018). Kostnader $i$ barnehager 2016 (Telemarksforsking rapport 426/2018). Hentet fra https://intra.tmforsk.no/publikasjoner/filer/3250.pdf

Nygård, M. (2017). Barnehagen som lceringsarena i endring. Politiske ideologier og barnehagelcereres fortolkninger (Doktoravhandling, Norges teknisk-naturvitenskapelige universitet). Hentet fra http://hdl.handle. net/11250/2451746

Næsguthe, I. \& Ravndal, S. K. L. (2018). Hva motiverer private barnehageeiere? (Masteroppgave, Norges Handelshøyskole). Hentet fra http://hdl.handle.net/11250/2559595

Pettersvold, M. \& Østrem, S. (2012). Mestrer, mestrer ikke: jakten på det normale barnet. Oslo: Res publica.

Pettersvold, M. \& Østrem, S. (2018). Profesjonell uro. Barnehagelcereres ansvar, integritet og motstand. Bergen: Fagbokforlaget.

Pettersvold, M. \& Østrem, S. (2019). Problembarna. Metoder og manualer $i$ barnehage, skole og barnevern. Oslo: Cappelen Damm Akademisk.

Rosa, H. (2010). Alienation and Acceleration. Towards a Critical Theory of Late-Modern Temporality. Aarhus: NSU Press.

Schofield, H. (2011). The Philosophy of Education: An Introduction. London: Routledge.

Seland, M. (2011). Livet $i$ den fleksible barnehagen. Oslo: Universitetsforlaget.

Sundsdal, E. \& Øksnes, M. (2015). Til forsvar for barns spontane lek. Nordisk Tidsskrift for Pedagogikk og Kritikk, 1, 1-11. https://doi.org/10.17585/ntpk.v1.89

Thuen, H. (2017). Den norske skolen. Utdanningssystemets historie. Oslo: Abstrakt forlag.

Øksnes, M. \& Sundsdal, E. (2018). Lekelyst $i$ barnehagen. Å fremme lekens egenverdi. Oslo: Cappelen Damm Akademisk.

Aabro, C. (2016). Koncepter $i$ pedagogisk arbejde. København: Hans Reitzels Forlag.

Aabro, C., Larsen, A. O. \& Pedersen, A. S. B. (2017). Programmering af pcedagogikken. Pcedagogers virke mellem koncept og kontekst. København: Juristforbundets Forlag. 